\title{
Impact of variable physical conditions and future increased aquaculture production on lice infestation pressure and its sustainability in Norway
}

\author{
Mari S. Myksvoll*, Anne D. Sandvik, Ingrid A. Johnsen, Jofrid Skarðhamar, \\ Jon Albretsen
}

Institute of Marine Research, 5817 Bergen, Norway

\begin{abstract}
Salmon lice infestation is a challenge for wild post-smolt salmon during migration from their natal river to the sea in several regions of Norway. The traffic-light management system regulates growth in the aquaculture industry, where growth in production $(6 \%)$ is only allowed if the impact of salmon lice on wild fish can be kept at a minimum and up to $10 \%$ mortality of wild salmonids are considered within the sustainability goal. We used a numerical ocean model, combined with an individual-based model for salmon lice, to evaluate the interannual variability in salmon lice concentrations in Production Zone 7, which was granted permission for production growth in 2017. Salmon lice releases were kept constant for $3 \mathrm{yr}$, while the physical conditions, e.g. wind and ocean circulation, varied. The total area of elevated lice infestations varied between 3.2 and $8.4 \%$ of the area within $5 \mathrm{~km}$ from the coast, due only to interannual physical variability mainly caused by variable wind patterns. Modeled post-smolts migrating out from the Namsen River $\left(64.5^{\circ} \mathrm{N}\right.$, central Norway) towards the open ocean experienced mortality between 5 and $9 \%$. Since Production Zone 7 was granted growth, we have simulated increased production and corresponding increases in lice releases. After 5 to 8 increments of $6 \%$ increase in production, the increase in salmon post-smolt mortality was of the same order of magnitude as the interannual variability. Information regarding migration route and time is crucial input to the model calculating post-smolt mortality, and inadequate information can affect the results significantly. These 2 methods (determining area of elevated lice infestations and estimating post-smolt mortality) provide complementary information and should be used in combination when the overall assessment of a production zone is made.
\end{abstract}

KEY WORDS: Salmon lice $\cdot$ Hydrodynamic model $\cdot$ Traffic-light system $\cdot$ Fjord $\cdot$ Dispersion model $\cdot$ Wind forcing $\cdot$ Norwegian coastal current

\section{INTRODUCTION}

Salmon louse Lepeophtheirus salmonis infestation is a challenge for wild post-smolt salmon Salmo salar during their migration from rivers to the sea in several regions of Norway (Serra-Llinares et al. 2014, Taranger et al. 2015, Halttunen et al. 2018). With increased aquaculture production of salmon in Norway over the past decade, the infestation pressure from salmon lice has also increased and is now threatening the survival of several wild salmon

${ }^{*}$ Corresponding author: marimy@imr.no stocks (Forseth et al. 2017) as well as causing welfare problems in farmed fish (Bui et al. 2019).

The greatest impact of salmon lice at present occurs in the westernmost part of Norway, where the aquaculture industry dominates (most densely distributed locations of farms), while in northern Norway, the impact has, until now, been considered acceptable for wild salmon (Myksvoll et al. 2018). This is illustrated in the so-called 'traffic-light system' (green-yellow-red), established by the government in 2017 for management of aquaculture pro- 
duction (Fig. 1). In this management system, the Norwegian coast was divided into 13 production zones to reduce transfer of lice between the zones (Ådlandsvik 2015). Every second year, an expert group assesses these areas for salmon lice-induced mortality of migrating salmon post-smolts based on field observations and numerical modeling (Nilsen et al. 2017, Kristoffersen et al. 2018, Vollset et al. 2018) and updates classification of each zone according to the traffic-light colour criteria, regulating the growth of production. Production growth is allowed in the green zones, not allowed in yellow zones and required to be reduced in red zones during the following 2 yr. This traffic-light assessment is based on the lice-induced mortality of wild salmon post-smolts of the 2 preceding years, in which the conditions can differ due to variable physical oceanographical conditions as well as the production cycle in the farms. The definition of sustainability provided by the Ministry of Trade, Industry and Fisheries (2015) indicates that no more than $10 \%$ mortality of wild salmonids

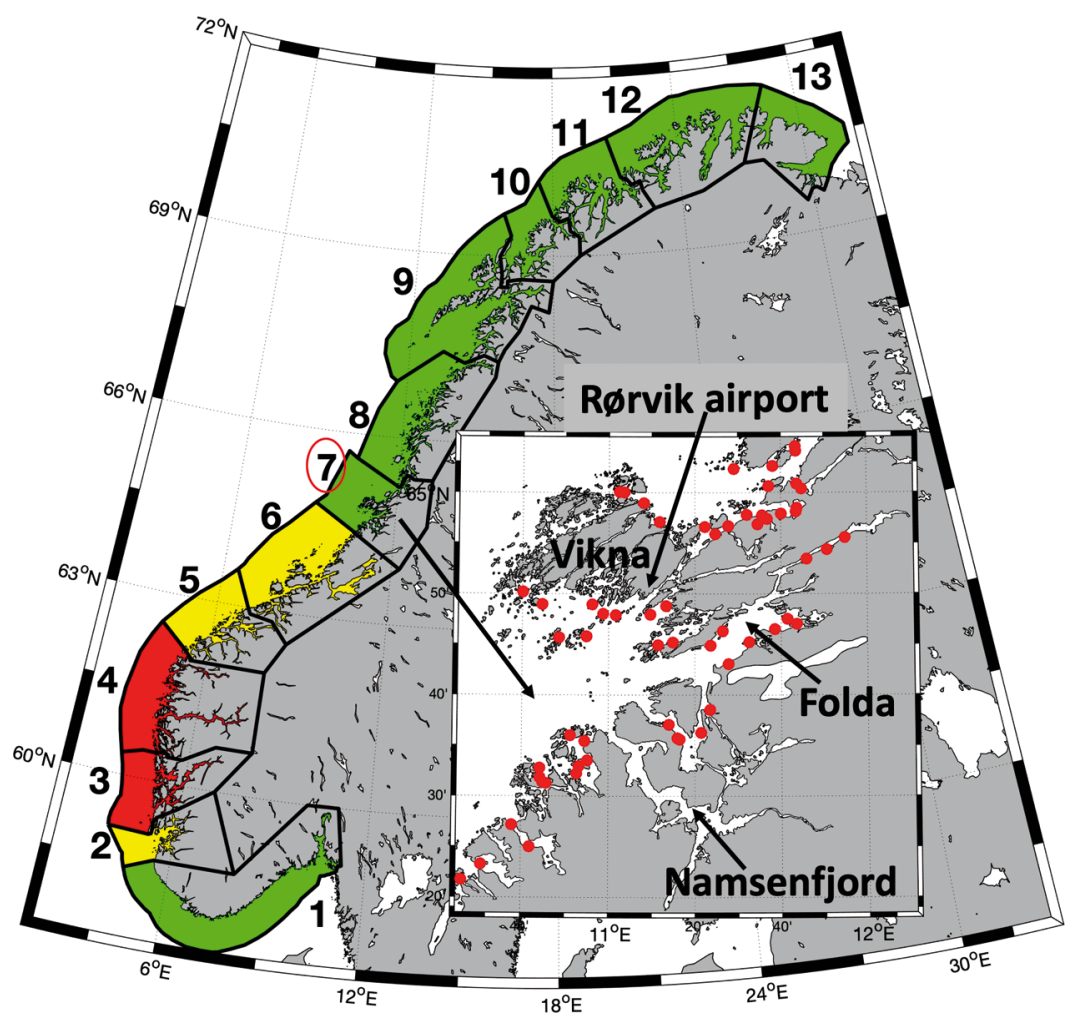

Fig. 1. Aquaculture traffic-light system in Norway in 2017. The 13 aquaculture production zones along the Norwegian coast were classified according to lice-induced mortality of wild migrating salmon post-smolts. Green indicates $<10 \%$ mortality and allows a $6 \%$ growth in aquaculture production; yellow indicates $10-30 \%$ mortality and therefore zero growth. Red denotes $>30 \%$ mortality and requires a $6 \%$ decrease in salmonid aquaculture production volume in those zones. Inset shows the study area in Production Zone 7 , where the red dots mark the positions of all fish farms used in this study caused by salmon lice is acceptable, and that the growth in production should be limited to areas that reach this sustainability goal. The traffic-light management system was first applied in 2017.

The lice concentrations in a given area depend on (1) the number of lice released from fish farms (which is the largest source of lice) and the locations of these farms and (2) the oceanography in the area, with varying currents transporting and distributing the lice in the water masses as they develop into infective copepodids (Asplin et al. 2014). The development rate of the lice depends on sea temperature (Stien et al. 2005, Hamre et al. 2019). The first factor, number of released lice, can be estimated based on the weekly reports of lice at each farm (the mean number of lice per fish) and the biomass (number of fish) in the pens (Sandvik et al. 2016). The uncertainty of these numbers is large, for both the reported numbers themselves and for the exact date when the lice were counted (Thorvaldsen et al. 2019). The reports of lice per fish are given to the Norwegian Food Safety Authority every week, while the biomass numbers are reported monthly; however, the exact date is not reported, only week number (for lice) and month (for biomass). The second factor, how the lice are dispersed in fjords and coastal areas, depends on the currents, which are variable and depend on winds, tides, freshwater runoff, and fjord-coast water exchange (e.g. Asplin et al. 2014, Johnsen et al. 2016, Skarðhamar et al. 2018). In hydrodynamic models, this variability in the currents is represented realistically, although the timing of events may be shifted by a few days or hours. The uncertainty of timing, both timing of released amounts lice and the timing of oceanographic events, has to be considered when analyzing the model results.

A hydrodynamic model system, using reported lice counts from all farms in Norway, was recently developed (Asplin et al. 2014, Johnsen et al. 2016). The salmon lice are represented with an individual-based model, and their vertical behavior is mainly controlled by an attraction towards light and an avoidance of low-salinity waters (Johnsen et al. 2014, Samsing et al. 2016, Brooker et al. 2018, Myksvoll et al. 2018). Recent lab experiments 
have shown that lice show a gradual avoidance of low-salinity waters (Crosbie et al. 2019), which is now implemented in the model (Sandvik et al. 2020). The model results have been compared with observations of lice attached to salmon post-smolts in sentinel cages (Sandvik et al. 2016, 2020) and on wildcaught fish (Johnsen et al. 2016, Myksvoll et al. 2018), and the modeled infestation pressure correlates well with observations.

We investigated how variable oceanographic conditions affect the distribution and concentrations of lice in the migration period of salmon post-smolts in Production Zone 7, which is considered a zone with uncertain assessment, balancing between 'yellow' and 'green' (Fig. 1). This production zone was scientifically advised to be 'yellow', but politically decided to be 'green' in 2017. This area has therefore experienced aquaculture production growth, despite the scientific advice of no increase in production. The main reason for deviating from the advice was large uncertainty in the assessment and a positive trend in the infestation pressure, meaning a reduction in the releases of salmon lice. We therefore investigated how robust the classification of this area was for variable oceanographic conditions as well as variable aquaculture production regimes. The interannual variation in production within Production Zone 7 is large, because the production alternates between south and north of the Vikna archipelago, and the release of lice can be expected to vary geographically in the same way. In addition, the wind conditions and the wind-driven surface currents during the 3 wk migration period of wild salmon post-smolts can vary from year to year.

The aim of this study was to assess the effects of interannual variability in the environment compared to increases in production on migrating wild salmon post-smolts from the Namsen River $\left(64.4^{\circ} \mathrm{N}\right)$ in Norway. We use a numerical model to simulate the distribution and concentrations of infective salmon lice in Production Zone 7, covering the migration route of salmon post-smolts from the Namsen River to the open ocean, for 3 yr (2016-2018) with constant salmon lice releases. The corresponding time period was chosen since the first evaluation of sustainability in the traffic-light management system was based on 2016-2017, and the second is based on 2018-2019. The wind conditions during the migration period varied between years, resulting in different wind-driven currents from year to year. We investigated the effect of variable wind and current conditions on infestation pressure for migrating post-smolts. By isolating the effects of the variable advective ocean currents (different between years) from the effects caused by differing production (variable release of lice nauplii in farms), we assessed how future increased aquaculture production, and consecutive increased number of lice released from farms, can affect the potential for sustainable aquaculture production in this area. It is important for both management authorities and local farmers to understand this interaction between oceanography and the release of lice when planning for a future sustainable salmon production.

\section{METHODS}

\subsection{Study area}

Production Zone 7 is located in central Norway $\left(64-65^{\circ} \mathrm{N}\right)$. The area consists of the Namsen fjord, several smaller fjord systems, and the Vikna archipelago, with 2 narrow straits connecting the northern and southern part of the production zone (Fig. 1). The Namsen fjord is a 'National Salmon Fjord', meaning that no farming is allowed within the fjord (SerraLlinares et al. 2014). The fjord is $42 \mathrm{~km}$ long, has a maximum depth of $468 \mathrm{~m}$ and a $200 \mathrm{~m}$ sill near the mouth. The Namsen River, discharging to the inner part of the fjord, is one of the most important salmon rivers in Norway (Moe et al. 2016), having the theoretical potential to produce more than 600000 wild salmon post-smolts per year (Nilsen et al. 2017). The river has an annual mean runoff of $246 \mathrm{~m}^{3} \mathrm{~s}^{-1}$ and is the seventh-largest river in Norway, based on the size of its drainage area. The post-smolt migration from the river towards the ocean is estimated to start on 14 May and continues until 23 June, with a median of 3 June (Thorstad et al. 1998). In total, there are 22 salmon rivers in the production zone with a total theoretical production of approximately 900000 wild salmon.

The migration route of salmon post-smolts after leaving the Namsen fjord mouth is unknown. The post-smolts have many possibilities, including moving directly southwest/west away from the coast into the Norwegian Sea, northwards towards the Vikna archipelago and then following the islands westward to the sea, or through the narrow straits and then offshore from the northern side of the archipelago. The different possible migration routes are subject to variable lice infestation pressure. Post-smolts choosing the northern route towards the archipelago and closer to the fish farms are probably more susceptible to higher infestation pressure than those taking more direct routes towards the open ocean. 


\subsection{Salmon lice release scenarios}

Since the Namsen fjord is protected under the Norwegian 'National Salmon Fjord' regulations, no farms are located within the fjord (Fig. 1). This means that salmon post-smolts leaving the Namsen River are partly protected inside the main fjord and normally first encounter the elevated infestation pressure on the coast after they leave the fjord. However, lice can occasionally be advected into the fjord through water exchange with the coastal waters even though there are no local sources of lice (Asplin et al. 2014).

The number of operational fish farms within a production zone varies between years. During the study period, the number of active farms in Production Zone 7 varied between 50 and 58 during the years 2012-2018 (locations shown in Fig. 1). The spatial distribution of production changes between years as a result of the 24 mo long production cycle. The most intensive production alternates between south and north of Vikna on a biennial basis. The lice level varies substantially between farms, weeks and years. The variation in Production Zone 7 was mainly between 0 and 1 louse per fish (2012-2018). Details on salmon lice releases from farms in Production Zone 7 are found in Fig. S1 in the Supplement at www.int-res.com/articles/suppl/q012p193_supp.pdf.

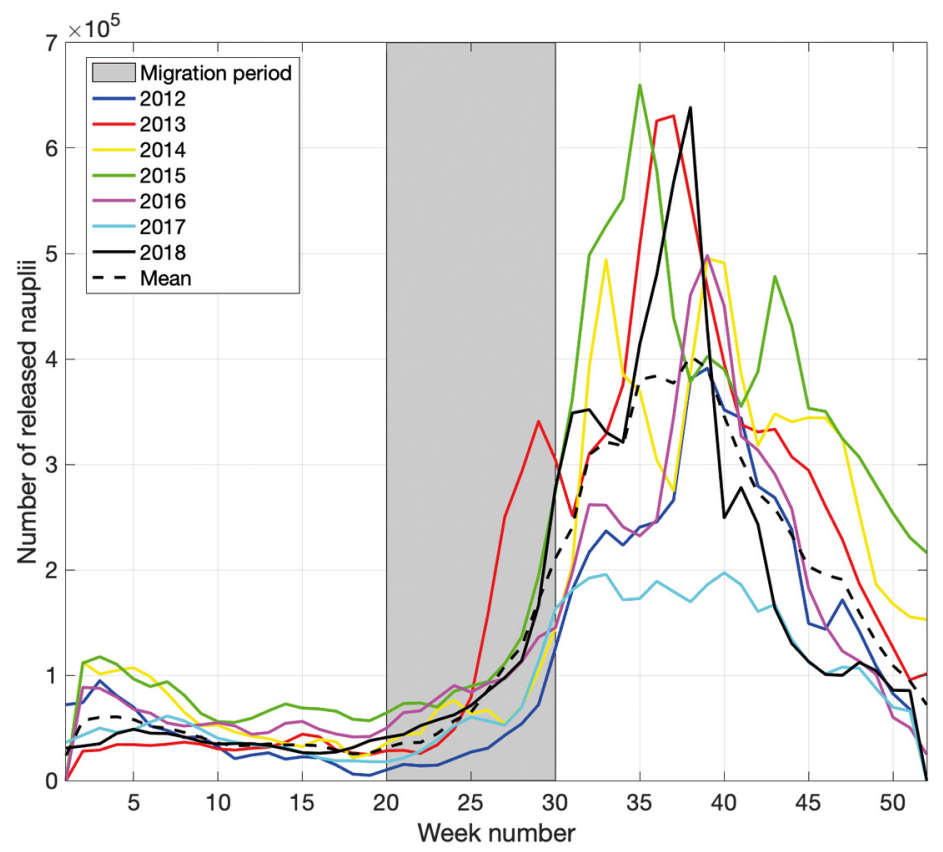

Fig. 2. Weekly mean salmon lice released from all farms (84 in total) for the years 2012-2018 (solid lines) and the overall mean. The grey shaded area marks the migration period for salmon post-smolts from the Namsen River
Due to large interannual variability in fish production and hence salmon lice releases from the different farms, we compiled data from 2012 until 2018. In total, 84 unique farms reported lice counts at least once during the $7 \mathrm{yr}$ period. However, many of the farms were only active for a limited time during the study period. The farms report temperature at $3 \mathrm{~m}$ depth and number of female lice per fish every week and the total number of fish every month. Based on these reports, the number of released lice was calculated according to Stien et al. (2005), assuming that a female louse can produce 150 eggs per string. Weekly releases of lice were calculated for each farm throughout 2012-2018, based on its own reported lice counts. We then averaged lice releases over all years at each farm every week, providing a weekly climatology (long-term mean) of lice releases at each farm. The same weekly climatology of lice releases was used in all years. Fig. 2 shows the mean release from all farms included in the analyses for the different years and the overall mean.

Based on the traffic-light management system, all farms in the green zone are allowed to increase their salmon production by $6 \%$ every second year. To create scenarios based on future increased production, we assumed that the lice releases also increased by $6 \%$. This assumption is a very simple approach to a complicated issue. Farms that are successful in lice prevention will be able to keep the lice level low even if the production increases. By combining several prevention techniques, like cleaner fish, functional feed, submerged feeding, deep attractant light and lice skirts, new lice infestations can be significantly reduced (Bui et al. 2020). However, the allowed number of female lice per fish is 0.2 (during spring, Week 16-21) and stays constant despite how many fish there are in the farm. Thus, an increase in $6 \%$ biomass will also cause an allowed increase of lice releases of $6 \%$. In addition, when the number of hosts (e.g. fish) within a certain area increases, the problem with parasites and diseases may accelerate due to the higher number of hosts (Jansen et al. 2012). An overview of the modeling scenarios is found in Fig. 3.

\subsection{Model system}

The full hydrodynamic ocean state was simulated with the open-source Regional Ocean Modeling System (ROMS, see e.g. Shchepetkin \& McWilliams 2005, Haidvogel et al. 2008; 


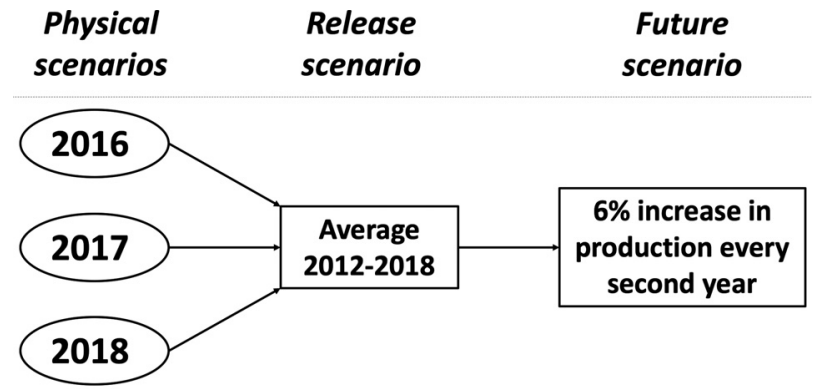

Fig. 3. Modeling approach. Three different physical scenarios were used (2016-2018) together with a simulated lice release based on the average from 2012 to 2018 . The future scenario included a biennial increase of $6 \%$ in salmon production from the average level in 2012-2018

http://myroms.org). ROMS is a free-surface, stateof-the-art, 3-dimensional, hydrostatic, primitive equation ocean model that uses generalized terrain-following s-coordinates in the vertical. The model grid covers the Namsen fjord and surrounding areas with $160 \times 160 \mathrm{~m}$ resolution in the horizontal $(173 \times$ $101 \mathrm{~km}$ ) and applies 35 vertical levels. To have a consistent and comparable hydrodynamic data set over 3 subsequent spring seasons for 2016-2018, the model set-up was fixed and the forcing data were retrieved from the same sources. The coastal region modeled consists of steep topography and narrow fjords, and high-resolution atmospheric forcing is necessary to e.g. control the intensified winds in this area. We then applied the AROME Meteorological Co-operation on Operational Numerical Weather Prediction (MetCoOp) $2.5 \mathrm{~km}$, which is the main forecasting system used by the Norwegian Meteorological Institute (Müller et al. 2017). Daily river flow rates for all main rivers were based on daily estimates from the Norwegian Water Resources and Energy Directorate. Hydrodynamic forcing along the open boundaries and initial fields were obtained from the numerical model NorKyst800 with $800 \times 800 \mathrm{~m}$ horizontal resolution (Albretsen et al. 2011), a coastal model also run operationally at the Norwegian Meteorological Institute (http://thredds.met.no). The tidal forcing was already included in the coastal model (TPXO7.2 global tidal analysis, Egbert \& Erofeeva 2002). The $160 \mathrm{~m}$ model was initiated on 1 March in every year (2016-2018) and lasted until 31 August to provide modeled current fields for the lice dispersion model (see Section 2.4) for 3 spring/summer seasons.

Different lateral boundary conditions were applied to exchange information from the coastal model (NorKyst800) to the fjord model. The Chapman boundary condition (Chapman 1985) was used for the free-surface boundary condition, and the Flather boundary condition (Flather 1976) was applied for the barotropic velocity. A radiation condition on the outflow and nudging to a known exterior value on inflow were applied for 3D momentum and tracers using 2 different timescales as described by Marchesiello et al. (2001). Our nudging on inflow was 120 times larger than on the outflow. For vertical turbulence, we applied the local closure scheme based on the generic length scale parameterization (Umlauf \& Burchard 2003).

\subsection{Particle tracking and salmon lice individual-based model}

Based upon the fields of current, temperature and salinity provided by the hydrodynamic model, the distribution of salmon lice from aquaculture locations was calculated using an open-source Lagrangian particle-tracking model. Every hour, 5 superparticles were released in the model from all farm locations, representing the calculated number of salmon lice. Different number of superparticles have been used in other studies, showing no differences in the result; thus 5 is a sufficient number (Johnsen et al. 2014, Sandvik et al. 2016, Myksvoll et al. 2018). The advection of particles was calculated using the fourth-order Runge Kutta scheme, solving the Lagrangian equation of motion with a timestep of $120 \mathrm{~s}$. Salmon lice are able to influence their distribution through vertical positioning in the water column (Johnsen et al. 2014). The particles were therefore given the ability to swim towards the surface during daytime and sink down to avoid water masses with low salinity in accordance with Sandvik et al. (2020). The particles representing salmon lice were assumed to be infective and able to attach to a host fish at an age between 40 and 170 degree-days in accordance with Samsing at al. (2016). Based upon these assumptions, the model estimated the concentration of lice in the model domain, updated hourly. The estimated distribution of lice using hydrodynamic model systems has previously been shown to coincide with observed levels of lice on fish in Norway (Johnsen et al. 2016, Samsing et al. 2016, Sandvik et al. 2016, 2020, Myksvoll et al. 2018). The use of hydrodynamic conditions to calculate the transportation and concentration of salmon lice is also widely used in the international community (Salama \& Murray 2011, Adams et al. 2012, 2015, 2016, Salama et al. 2013, 2016, 2018, Samsing et al. 2017, Cantrell et al. 2018). 


\subsection{Relative operating characteristic (ROC)}

The post-processed output from the salmon lice dispersion model is the number of infective lice larvae $\mathrm{m}^{-2}$, integrated over the upper $2 \mathrm{~m}$. To relate this to the number of lice on wild fish, the model data were calibrated against lice on hatchery-reared Atlantic salmon post-smolts held in sentinel cages in the Hardangerfjord using a binary forecast system, the empirical ROC (Sandvik et al. 2016, 2020), which is used to predict areas of elevated lice concentrations, where the threshold value is derived from observations. Based on extensive experience and field observations on lice abundance in hatcheryreared and sentinel-caged post-smolts over several years and large areas along the coastline (Asplin et al. 2011, Bjørn et al. 2011), the sentinel cage infestation was classified into 4 classes: low (0-1 louse fish $\left.^{-1}\right)$, moderate (1-5 lice fish $\left.{ }^{-1}\right)$, medium (5-10 lice fish $^{-1}$ ) and high $\left(>10\right.$ lice fish $^{-1}$ ) after being deployed for $2 \mathrm{wk}$. To better reflect the classes used in the traffic-light system (low, medium, high), Classes 2 and 3 were merged in the present study, thus 10 lice fish ${ }^{-1}$ was used to classify the limit of high infestation pressure and 1 louse fish ${ }^{-1}$ was used to separate low and medium infestation pressure. The corresponding thresholds in the model are 1.8 lice $\mathrm{m}^{-2}$ for the high limit and 0.7 lice $\mathrm{m}^{-2}$ for the low limit (Sandvik et al. 2020).

Horizontal ROC maps can be interpreted as the results of virtual post-smolt cages that have been deployed in a fine mesh grid in the area of interest, where red/yellow/green means that a wild salmonid fish, swimming around at the given location, will probably be infected by $>10$, between 1 and 10, and $<1$ lice, respectively. For a more detailed description, see Sandvik et al. $(2016,2020)$.

\subsection{Post-smolt model}

To evaluate the level of salmon lice on outmigrating salmon, a post-smolt model was developed. The model simulates post-smolts swimming from their natal river to the open ocean and is 1-way nested in the modeled concentration of salmon lice. The infestation of lice on the virtual post-smolts is based upon the model-estimated concentration of salmon lice and is calibrated to match the level of lice observed on wild out-migrating post-smolts captured by trawl. Information of detailed swimming routes for specific rivers is limited; therefore, the model fish is parameterized to swim the shortest route towards the open ocean, with swimming velocity in accordance with observations (see Johnsen et al. 2019 for model details). Based upon earlier published tolerance limits of salmon lice, the mortality of the post-smolts due to lice infestations was estimated in our model (Taranger et al. 2015, Johnsen et al. 2019).

To evaluate the effect of the release scenarios on wild post-smolts, the model was run for fish from the Namsen River for all scenarios shown in Fig. 3. The post-smolts migrating from Namsen were assumed to reach the open ocean and were excluded from further calculations when they reached a model point with no land within $20 \mathrm{~km}$. This way, we extended the modeled swimming route to include the entire area covered by lice, including far away from land. The area assumed for salmon post-smolt migration and lice exposure is shown by gray shading in Fig. 4 .

\section{RESULTS}

\subsection{Interannual variability in lice dispersion}

The lice dispersion modeling showed that the interannual variability in both horizontal extent and concentration is considerable (Fig. 4). The lice were transported further offshore in the 2016 simulation compared to the other 2 years, when the highest lice concentrations were found closer to the coast and inside Folda Bay. The wind pattern in June 2016 was different from the other years, with prevailing northerly winds, while southwesterly winds dominated the same period in 2017 and 2018 (Fig. 4). Northerly winds push the surface layer away from the coast, as seen in the 2016 simulation, causing strong mixing and therefore lower concentrations of lice distributed over a larger area. Southwesterly winds push the surface layer towards the coast, as seen in 2017 and 2018, causing high concentrations of lice in the innermost part. When surface water including lice is pushed towards the coast, the resulting concentrations exceed the threshold for elevated lice infestation, and thus the ROC maps show a larger red area (Fig. 5). The strongest southwesterly winds in 2018 also coincide with the largest red area.

There is no local source of lice within the Namsen Fjord in this model setup since the fjord is protected and lice releases from wild fish were not included. Nevertheless, lice were transported into the fjord during all years in June (Fig. 4), especially during 2018, when lice were transported far inside the fjord due to strong southwesterly winds. 
The modeled salmon post-smolt migration routes (Fig. 4) showed different overlapping areas of high lice concentrations in the 3 years. The modeled mortality of salmon post-smolts from Namsen was $11 \%$ in 2016, $7 \%$ in 2017, and $10 \%$ in 2018 (Fig. 6). The postsmolts were partly protected from lice during the first part of the migration through the Namsen Fjord, except during years with high inflow of lice from the outer part (as in 2018). However, as the postsmolts left the protected fjord, they may have been at high risk of encountering high lice concentrations in the coastal water. Assuming that the post-smolts followed a direct route towards the open ocean, they will have avoided the red area south of Vikna and in-
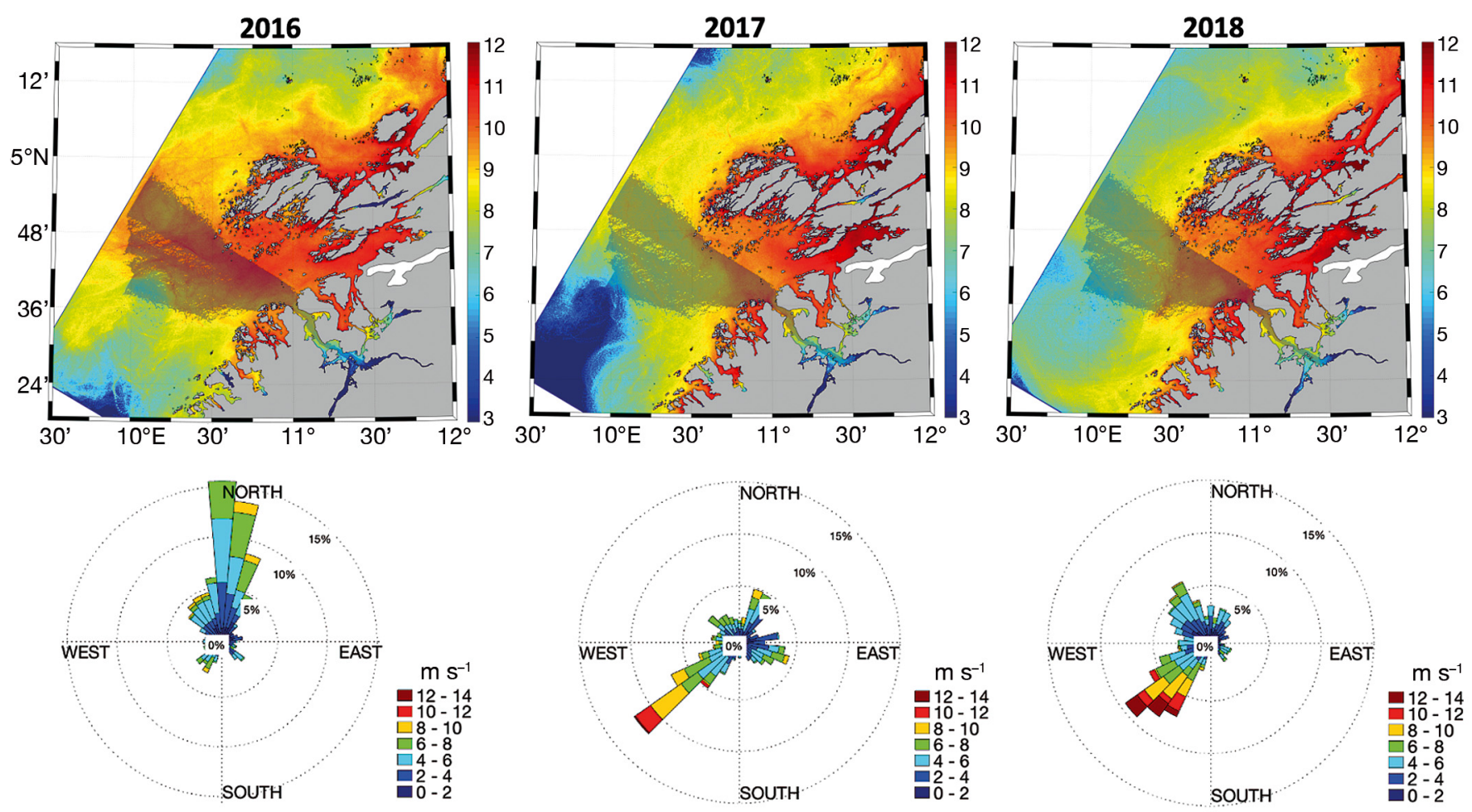

Fig. 4. Mean monthly horizontal distribution of lice copepodids (no. $\mathrm{m}^{-2}$ ) with identical lice releases during June in 3 different years $(2016,2017$ and 2018), with salmon post-smolt migration route shown in the shaded area (upper panels). The lower panels show the prevailing wind intensity and direction at Rørvik airport $\left(64.84^{\circ} \mathrm{N}, 11.14^{\circ} \mathrm{E}\right)$ during the same time period
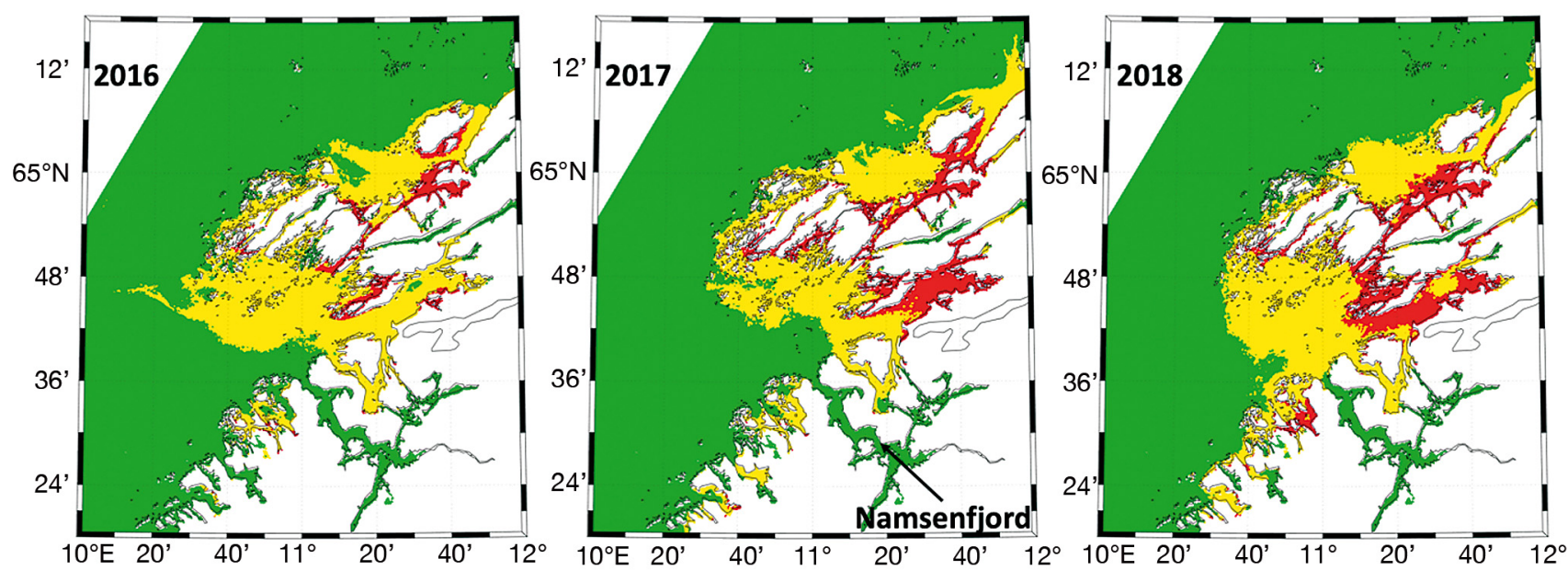

Fig. 5. Calculated areas of elevated lice infection pressure (relative operating characteristic maps) separated into high (red), moderate (yellow) and low (green) risk areas during the salmon post-smolt migration period from 20 May to 17 June for the 3 study years (2016-2018) 
side Folda. During years with predominant northerly winds (like 2016), the potential encounter rates between lice and post-smolts were much higher, even though the lice concentrations were lower.

\subsection{Future scenarios with increased biomass}

Simulations with biennial $6 \%$ increases in the numbers of lice released from the farms showed an increase in red and yellow areas (Fig. 6a) and an increase in mortality of salmon post-smolts (Fig. 6b) during 20 increments of lice releases, corresponding to $40 \mathrm{yr}$ of growth. Generally, there was a steady increase with no abrupt changes. On average, 7 increments were required to double the red area within $5 \mathrm{~km}$ off the coast; $30 \%$ of the area near the coast was red after 20 (2016), 19 (2017) and 15 (2018) increments.

The interannual variability in mortality of salmon post-smolts ranged from 7 to $11 \%$. After 5 increments from the 2016 and 2018 reference levels, the increase was of the same order of magnitude as the interannual variability. However, from the 2017 reference level, it took 8 increments to reach the same level of variability.

The highest infestation level was mainly restricted to the inner part of the production zone, where the lice concentrations were sufficiently high. If the salmon post-smolts migrate directly towards the open ocean, they can still avoid the red area after several incremental increases. However, the risk of encountering high infestation pressure is large since all other migration routes will bring the post-smolts towards areas with high concentrations of lice.

\section{DISCUSSION}

The present management system of Norwegian aquaculture regulates production in each zone for the 2 coming years based on lice infestation pressure over the 2 preceding years. We investigated the impact of variable physical conditions and increased production on lice infestation pressure in a production zone which has an uncertain assessment of sustainability. For planning more than 2 years ahead, it is important to understand how the dynamics between the physical oceanography (currents, winds, water exchange etc.) and the variable release of lice from farms (time and space) affect the distribution of lice in an area and thereby which color can be expected in the traffic-light management system in the future.

\subsection{Interannual variability compared to future increase}

Large interannual variability in the wind-driven circulation pattern had a large impact on the local infestation pressure in the region. Even when the lice releases were kept constant, the horizontal distribu-
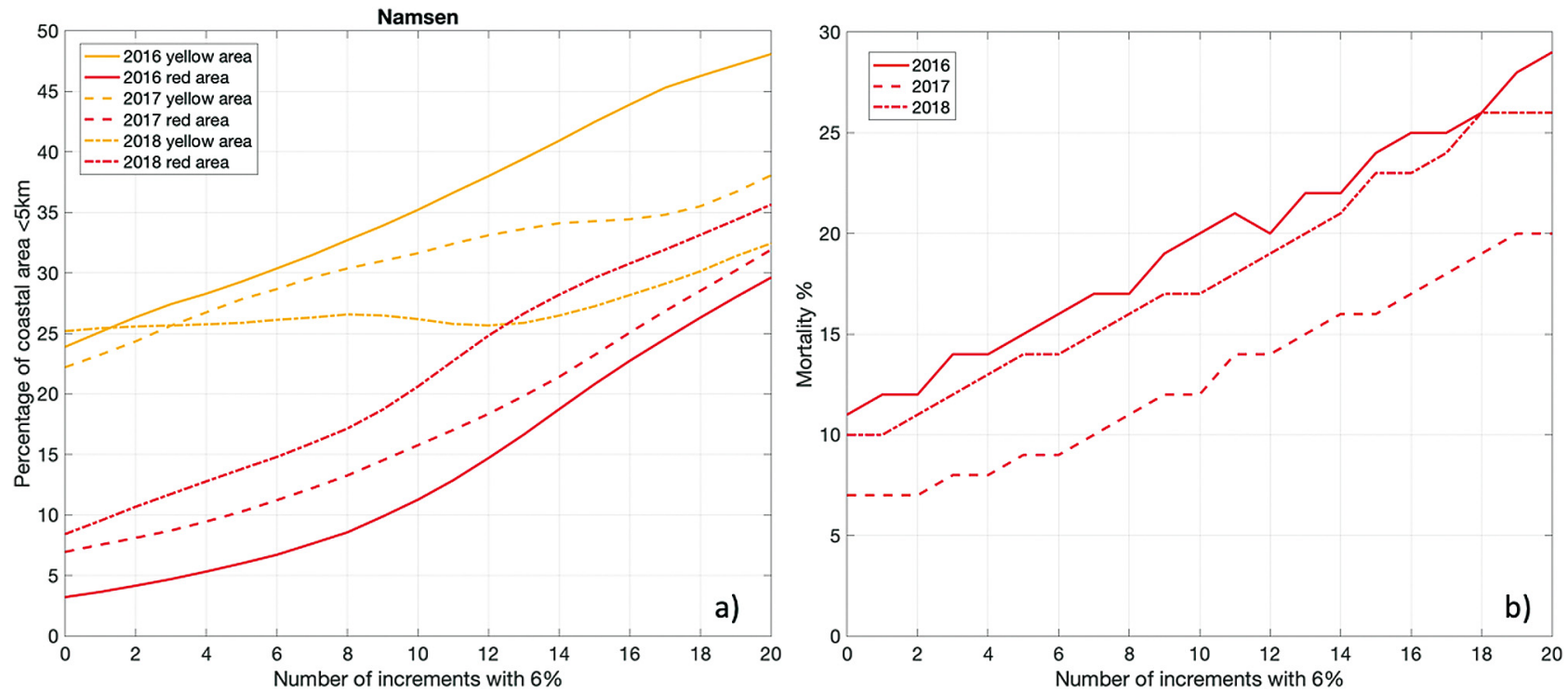

Fig. 6. (a) Total percentage of red and yellow areas in the entire production zone (within $5 \mathrm{~km}$ from the coast) as a function of $6 \%$ increments in salmon production, comparing the 3 reference years (2016, 2017 and 2018). (b) Modeled mortality from the virtual post-smolt model when they reached $20 \mathrm{~km}$ from the nearest land point with constant lice releases in the 3 different physical scenarios 
tion in June varied significantly among the 3 study years (2016-2018) and the total red area ranged between 3.2 and $8.4 \%$ of the area within $5 \mathrm{~km}$ from the coast. The main difference causing this large interannual change in dispersal was the wind pattern. Northerly winds and offshore transport in 2016 spread the lice out into a larger area; the overall concentration was therefore lower and the red area smaller. The southwesterly winds in 2017 and 2018 pushed the water and the lice towards the coast, giving rise to a larger red area. Wind data from the last 15 yr (2005-2019) show that both situations, northerly and southwesterly winds, are equally frequent weather patterns in June (Fig. S1).

The physical conditions during the relevant time period in a specific year have a large influence on the mean intensity of lice and the corresponding mortality of post-smolts migrating from the Namsen River. In the worst of the 3 study years (2016, with $11 \%$ mortality), a larger area was exposed to lice even though the concentration was low, which in turn caused a larger overlap with the salmon post-smolt migration route. However, all study years showed that the migration route we chose is the least liceexposed route from the Namsen fjord towards the open ocean. All other routes, either southwards along the coast or north towards the Vikna archipelago, would be more exposed to lice than the direct route that we chose. Due to large uncertainty in the migration pattern of post-smolts, our estimates of mortality are a conservative estimate of the risk of lice-induced mortality.

In this study, we chose weekly climatological releases of lice, not varying between years, to be able to compare the physical variability between years. The advice given for the traffic-light management evaluation is based on realistic nauplii releases for a specific year. For the years discussed here, the estimated post-smolt mortality for Namsen was 9, 6, and $5 \%$ for 2016, 2017, and 2018, respectively (Johnsen et al. 2019). The production was mainly south of Vikna in 2016 and 2018, and north of Vikna in 2017. The variability in mortality $(4 \%)$ between years for these realistic simulations has the same range as our simulations, using weekly climatology of lice releases and only varying the oceanographic conditions. This comparison shows that interannual variability in physical conditions causes the same order of magnitude in lice release variability as the interannual changes in production cycles and irregularities on each fish farm.

When the release of nauplii increased as a consequence of increased production, both the total red area and estimated mortality increased steadily. Nevertheless, up to 8 increments were required to match the interannual range for mortality and up to 7 increments for the red area. This means that when the physical conditions are favorable, it is possible to increase the production by $7-8$ increments and still be within the interannual lice variability. However, considering the least favorable physical conditions, no increments would be possible within the present regime.

\subsection{Sources of uncertainty}

We assumed that an increase in fish biomass would also result in a corresponding increase in salmon lice nauplii released from the farms. This assumption is a simplification of a complicated process, and it is known that when the host density increases, so does the problem with parasites, potentially exponentially (Jansen et al. 2012). If nonlinear parasite interactions were included, it is likely that the total red area and the estimated smolt mortality would increase more rapidly than what is presented in Fig. 6. Again, it is important to emphasize that the future estimate of released nauplii is conservative, assuming a linear increase of both fish production and lice releases.

There are large uncertainties related to the migration of salmon post-smolts from the Namsen River, both in timing and in specific migration route (Thorstad et al. 2012). Most of the research on migration has focused on the inner part of estuaries (Thorstad et al. 2004, 2007) and the freshwater environment in the river itself (Thorstad et al. 1998). Halttunen et al. (2018) found that migration was strongly influenced by ocean currents, and higher residence time in the fjord could result in lethally high lice infestations. Ounsley et al. (2020) investigated different swimming behavior scenarios that included current-oriented and compass-oriented movement along the Scottish continental shelf. The majority of these studies were made in fjord systems where the salmon post-smolts experience higher lice densities within the fjord compared to outside. The Namsen fjord system is the complete opposite; since the main fjord is protected from salmon production, the post-smolts will have a higher risk of encountering lice after leaving the fjord and entering the open ocean. The behavior of post-smolts in a system like this is therefore unknown. A continuous direct route towards the open ocean minimizes the risk of lice encounters; however, any route along the coast, either north or south, will result in a large risk of high lice densities. If the post-smolts are able to detect and avoid high lice densities, they should seek 
the open ocean, but in this dynamic environment, there is still a considerable risk of encountering lice patches and eddies.

Here we assumed increased production and corresponding lice releases from existing locations, but increased production may be granted in new locations within the production zone. It is possible to only allow increased production at locations (both new and existing) that have a low impact on the migration routes of wild fish, specifically from the Namsen River. Samsing et al. (2019) demonstrated how it is possible to 'break' up an existing network of fish farms on a national scale; this approach should also be applied within the production zones to secure an optimal distribution of farms and could allow for further growth within the sustainability goal.

In this study, we used a $160 \times 160 \mathrm{~m}$ horizontal resolution model covering only Production Zone 7 . The production zones are constructed through clustering analysis to reduce the transport between zones. However, the southern border, between Zones 6 and 7 , is the weakest border with the highest percentage of import of lice $(3.8 \%)$ of all the production zones (Ådlandsvik 2015). This is mainly due to several large fish farms in the northern part of Production Zone 6, short geographical distances, and a relatively steady northwards flow with the Norwegian Coastal current. We have probably underestimated the total number of lice in this area since we have not included lice imported from production zones further south. However, given that the traffic-light management system is designed to keep the production zones as separate management units, we chose not to include the import factor here.

\section{CONCLUSION}

According to the traffic-light management system, the limit for sustainability is $10 \%$ lice-induced mortality on salmon post-smolts. These simulations show that this limit has already been reached for Namsen post-smolts or will be reached after 7 increments (for 2018). However, the overall conclusion for Production Zone 7 must include an evaluation of all salmon rivers in the area even though Namsen River is the most important one.

Two methods were used to 'translate' the direct model output into a risk assessment for salmon liceinduced mortality of wild fish, namely virtual postsmolts and ROC maps (red area). The methods are fundamentally different but still equally important for an overall assessment of an entire production zone. If the methods were applied individually, the conclusion would differ due to their fundamental differences. It is important to emphasize that neither of the methods is wrong, but the assumptions made initially will have a major influence on the conclusion. To be able to evaluate the sustainability within a production zone, both methods should be used. The 2 methods show different results when evaluating which of the years (2016-2018) has the highest risk for lice-induced mortality on wild fish.

The main advantage with using a virtual post-smolt model to evaluate lice-induced mortality on wild postsmolts is that the model output is 'translated' into lice counts on fish and corresponding lice intensity and mortality, which are easier to interpret when the model results are evaluated. However, the decisions on specific migration routes and timing when building the model have a major impact on the end product. This case study is special since post-smolts from Namsen River are to a large extent protected from lice during their migration through the main fjord, but the risk of encountering high lice concentrations increases dramatically after leaving the fjord mouth. The least affected route is the direct route towards the open ocean, which was used in the virtual post-smolt model. All other routes, either southwards or northwards along the coast, will expose post-smolts to higher infestation pressure; thus, the estimated mortality is a conservative estimate of the risk that salmon post-smolts will encounter in a future scenario.

The ROC maps provide an estimate of the area of elevated lice infestation pressure in the entire production zone, which is a very useful parameter even though it is not directly related to mortality of wild fish. However, a wild fish that remains within the red area for the time period over which the map is integrated will experience a lethal dose of lice. The ROC maps provide a risk assessment of the entire production zone, and no effort is made to geographically limit the area to include the actual habitat of wild fish. Some might argue that geographical information must be included; otherwise, the output is irrelevant. However, considering the uncertainties in the virtual post-smolt model, we argue that it is necessary to include the entire production zone in the assessment; otherwise, the risk might be underestimated, as shown in this case study. The 2 methods, i.e. the virtual post-smolt model and ROC maps, are complementary methods that should be used together. The virtual post-smolt model was developed only for salmon post-smolts, while the ROC maps provide information relevant for both sea trout Salmo trutta and Arctic char Salvelinus alpinus. 
Acknowledgements. This work was funded by the Norwegian Research Council through the project 'Regional lice assessment - REGLICE', project number 244439. We thank Gunnar Livik for providing wind data from the Norwegian Meteorological Institute.

\section{LITERATURE CITED}

Adams T, Black K, MacIntyre C, MacIntyre I, Dean R (2012) Connectivity modelling and network analysis of sea lice infection in Loch Fyne, west coast of Scotland. Aquacult Environ Interact 3:51-63

Adams TP, Proud R, Black KD (2015) Connected networks of sea lice populations: dynamics and implications for control. Aquacult Environ Interact 6:273-284

Adams TP, Aleynik D, Black KD (2016) Temporal variability in sea lice population connectivity and implications for regional management protocols. Aquacult Environ Interact 8:585-596

Ådlandsvik B (2015) Forslag til produksjonsområder i norsk lakse- og ørretoppdrett. Rapport fra Havforskningsinstituttet, 20-2015. Institute of Marine Research, Bergen

Albretsen J, Sperrevik AK, Staalstrøm A, Sandvik AD, Vikebø F, Asplin L (2011) NorKyst-800 report no. 1: User manual and technical descriptions. Fisken og havet. www.hi.no/resources/publikasjoner/fisken-og-havet/ 2011/fh_2-2011_til_web.pdf

Asplin L, Boxaspen KK, Sandvik AD (2011) Modeling the distribution and abundance of planktonic larval stages of Lepeophtheirus salmonis in Norway. In: Jones S, Barnes $\mathrm{R}$ (eds) Salmon lice: an integrated approach to understanding parasite abundance and distribution. WileyBlackwell, Oxford, p 31-50

Asplin L, Johnsen IA, Sandvik AD, Albretsen J, Sundfjord V, Aure J, Boxaspen KK (2014) Dispersion of salmon lice in the Hardangerfjord. Mar Biol Res 10:216-225

Bjørn PA, Sivertsgård R, Finstad B, Nilsen R, Serra-Llinares RM, Kristoffersen R (2011) Area protection may reduce salmon louse infection risk to wild salmonids. Aquacult Environ Interact 1:233-244

Brooker AJ, Skern-Mauritzen R, Bron JE (2018) Production, mortality, and infectivity of planktonic larval sea lice, Lepeophtheirus salmonis (Krøyer, 1837): current knowledge and implications for epidemiological modelling. ICES J Mar Sci 75:1214-1234

* Bui S, Oppedal F, Sievers M, Dempster T (2019) Behavior in the toolbox to outsmart parasites and improve fish welfare in aquaculture. Rev Aquacult 11:168-186

* Bui S, Nilsson J, Stien LH, Trengereid H, Oppedal F (2020) Efficiency and welfare impact of long-term simultaneous in situ management strategies for salmon louse reduction in commercial sea cages. Aquaculture 520: 734934

* Cantrell DL, Rees EE, Vanderstichel R, Grant J, Filgueira R, Revie CW (2018) The use of kernel density estimation with a bio-physical model provides a method to quantify connectivity among salmon farms: spatial planning and management with epidemiological relevance. Front Vet Sci 5:269

Chapman DC (1985) Numerical treatment of cross-shelf open boundaries in a barotropic coastal ocean model. J Phys Oceanogr 15:1060-1075

Crosbie T, Wright DW, Oppedal F, Johnsen IA, Samsing F, Dempster T (2019) Effects of step salinity gradients on salmon lice larvae behaviour and dispersal. Aquacult Environ Interact 11:181-190

Egbert GD, Erofeeva SY (2002) Efficient inverse modeling of barotropic ocean tides. J Atmos Ocean Technol 19:183-204

Flather R (1976) A tidal model of the northwest European continental shelf. Mem Soc R Sci Liege 10:141-164

* Forseth T, Barlaup BT, Finstad B, Fiske P and others (2017) The major threats to Atlantic salmon in Norway. ICES J Mar Sci 74:1496-1513

*Haidvogel D, Arango H, Budgell W, Cornuelle B and others (2008) Ocean forecasting in terrain-following coordinates: formulation and skill assessment of the Regional Ocean Modeling System. J Comput Phys 227:3595-3624

*Halttunen E, Gjelland KØ, Glover KA, Johnsen IA and others (2018) Migration of Atlantic salmon post-smolts in a fjord with high infestation pressure of salmon lice. Mar Ecol Prog Ser 592:243-256

*Hamre LA, Bui S, Oppedal F, Skern-Mauritzen R, Dalvin S (2019) Development of the salmon louse Lepeophtheirus salmonis parasitic stages in temperatures ranging from 3 to $24^{\circ} \mathrm{C}$. Aquacult Environ Interact 11:429-443

Jansen PA, Kristoffersen AB, Viljugrein H, Jimenez D, Aldrin M, Stien A (2012) Sea lice as a density-dependent constraint to salmonid farming. Proc R Soc B 279: 2330-2338

Johnsen IA, Fiksen Ø, Sandvik AD, Asplin L (2014) Vertical salmon lice behaviour as a response to environmental conditions and its influence on regional dispersion in a fjord system. Aquacult Environ Interact 5:127-141

Johnsen IA, Asplin LC, Sandvik AD, Serra-Llinares RM (2016) Salmon lice dispersion in a northern Norwegian fjord system and the impact of vertical movements. Aquacult Environ Interact 8:99-116

* Johnsen IA, Sævik PN, Ådlandsvik B (2019) Utvandring av virtuell smolt 2018/2019. Rapport fra Havforskningen, 55-2019. www.hi.no/hi/nettrapporter/rapport-fra-havfors kningen-2019-55

Kristoffersen AB, Qviller L, Helgesen KO, Vollset KW, Viljugrein H, Jansen PA (2018) Quantitative risk assessment of salmon louse-induced mortality of seaward-migrating post-smolt Atlantic salmon. Epidemics 23:19-33

Marchesiello P, McWilliams JC, Shchepetkin A (2001) Open boundary conditions for long-term integration of regional oceanic models. Ocean Model 3:1-20

Ministry of Trade, Industry and Fisheries (2015) Predictable and environmentally sustainable growth in the Norwegian salmon and trout farming (Meld. St. 16, 2014-2015). Ministry of Trade, Industry and Fisheries. https://www. regjeringen.no/no/dokumenter/meld.-st.-16-2014-2015/ id2401865/? ch=1\&q (in Norwegian)

*Moe K, Næesje TF, Haugen TO, Ulvan EM, Aronsen T, Sandnes T, Thorstad EB (2016) Area use and movement pattern of wild and escaped farmed Atlantic salmon before and during spawning in a large Norwegian river. Aquacult Environ Interact 8:77-88

Müller M, Homleid M, Ivarsson KI, Køltzow MAØ and others (2017) AROME-MetCoOp: a Nordic convective-scale operational weather prediction model. Weather Forecast 32:609-627

*Myksvoll MS, Sandvik AD, Albretsen J, Asplin L and others (2018) Evaluation of a national operational salmon lice monitoring system - from physics to fish. PLOS ONE 13: e0201338

Nilsen F, Ellingsen I, Finstad B, Jansen PA and others (2017) Vurdering av lakselusindusert villfiskdødelighet per pro- 
duksjonsområde. Rapport fra ekspertgruppe for vurdering av lusepåvirkning. www.regjeringen.no/contentassets/ b352699b485d471fa50b9efdffb28dce/ekspertgruppe_ hovedrapporten_2017.pdf

Ounsley JP, Gallego A, Morris DJ, Armstrong JD (2020) Regional variation in directed swimming by Atlantic salmon smolts leaving Scottish waters for their oceanic feeding grounds - a modelling study. ICES J Mar Sci 77: 315-325

Salama NKG, Murray AG (2011) Farm size as a factor in hydrodynamic transmission of pathogens in aquaculture fish production. Aquacult Environ Interact 2:61-74

Salama NKG, Collins CM, Fraser JG, Dunn J, Pert CC, Murray AG, Rabe B (2013) Development and assessment of a biophysical dispersal model for sea lice. J Fish Dis 36: 323-337

Salama NKG, Murray AG, Rabe B (2016) Simulated environmental transport distances of Lepeophtheirus salmonis in Loch Linnhe, Scotland, for informing aquaculture area management structures. J Fish Dis 39:419-428

Salama NKG, Dale AC, Ivanov VV, Cook PF, Pert CC, Collins CM, Rabe B (2018) Using biological-physical modelling for informing sea lice dispersal in Loch Linnhe, Scotland. J Fish Dis 41:901-919

Samsing F, Oppedal F, Dalvin S, Johnsen I, Vågseth T, Dempster T (2016) Salmon lice (Lepeophtheirus salmonis) development times, body size, and reproductive outputs follow universal models of temperature dependence. Can J Fish Aquat Sci 73:1841-1851

Samsing F, Johnsen I, Dempster T, Oppedal F, Treml EA (2017) Network analysis reveals strong seasonality in the dispersal of a marine parasite and identifies areas for coordinated management. Landsc Ecol 32:1953-1967

Samsing F, Johnsen I, Treml EA, Dempster T (2019) Identifying 'firebreaks' to fragment dispersal networks of a marine parasite. Int J Parasitol 49:277-286

Sandvik AD, Bjørn PA, Ådlandsvik B, Asplin L and others (2016) Toward a model-based prediction system for salmon lice infestation pressure. Aquacult Environ Interact 8:527-542

Sandvik AD, Johnsen IA, Myksvoll M, Sæevik PN, Skogen MD (2020) Prediction of salmon lice infestation pressure in a Norwegian fjord. ICES J Mar Sci 77:746-756

Serra-Llinares RM, Bjørn PA, Finstad B, Nilsen R, Harbitz A, Berg M, Asplin L (2014) Salmon lice infection on wild salmonids in marine protected areas: an evaluation of the

Editorial responsibility: Bengt Finstad,

Trondheim, Norway
Norwegian 'National Salmon Fjords'. Aquacult Environ Interact 5:1-16

Shchepetkin AF, McWilliams JC (2005) The regional oceanic modeling system (ROMS): a split-explicit, free-surface, topography-following-coordinate oceanic model. Ocean Model 9:347-404

Skarðhamar J, Albretsen J, Sandvik AD, Lien VS and others (2018) Modelled salmon lice dispersion and infestation patterns in a sub-arctic fjord. ICES J Mar Sci 75: 1733-1747

Stien A, Bjørn PA, Heuch PA, Elston DA (2005) Population dynamics of salmon lice Lepeophtheirus salmonis on Atlantic salmon and sea trout. Mar Ecol Prog Ser 290: 263-275

* Taranger GL, Karlsen Ø, Bannister RJ, Glover KA and others (2015) Risk assessment of the environmental impact of Norwegian Atlantic salmon farming. ICES J Mar Sci 72: 997-1021

Thorstad EB, Heggberget TG, Økland F (1998) Migratory behavior of adult wild and escaped farmed Atlantic salmon, Salmo salar L., before, during and after spawning in a Norwegian river. Aquacult Res 29:419-428

* Thorstad EB, Økland F, Finstad B, Sivertsgård R, Bjørn PA, McKinley S (2004) Migration speeds and orientation of Atlantic salmon and sea trout post-smolts in a Norwegian fjord system. Environ Biol Fishes 71:305-311

* Thorstad EB, Økland F, Finstad B, Sivertsgård R, Plantalech N, Bjørn PA, McKinley RS (2007) Fjord migration and survival of wild and hatchery-reared Atlantic salmon and wild brown trout post-smolts. Hydrobiologia 582: 99-107

Thorstad EB, Whoriskey F, Uglem I, Moore A, Rickardsen AH, Finstad B (2012) A critical life stage of the Atlantic salmon Salmo salar: behavior and survival during the smolt and initial post-smolt migration. J Fish Biol 81: 500-542

Thorvaldsen T, Frank K, Sunde LM (2019) Practices to obtain lice counts at Norwegian salmon farms: status and possible implications for representativity. Aquacult Environ Interact 11:393-404

Umlauf L, Burchard H (2003) A generic length-scale equation for geophysical turbulence models. J Mar Res 61: 235-265

Vollset KW, Dohoo I, Karlsen Ø, Halttunen E and others (2018) Disentangling the role of sea lice on the marine survival of Atlantic salmon. ICES J Mar Sci 75:50-60

Submitted: November 26, 2019; Accepted: March 13, 2020

Proofs received from author(s): April 28, 2020 